\title{
INOVASI TEKNIK PEMBELAJARAN PENDIDIKAN AGAMA ISLAM PADA MAN 2 MEDAN
}

\author{
Muhizar Muchtar \\ Dosen Universitas Sumatera Utara, Universitas Negeri Medan dan \\ STAI Jam'iyah Mahmudiyah
}

\begin{abstract}
This paper is related to innovation learning Islamic education in the MAN 2 Medan. The problem studied is how the shape of the learning technique innovation? How its effectiveness? And how students respond to learning techniques such innovation? The results showed: the form of technical innovation of Islamic education in MAN 2 Medan models include: development of methods and inquiri diskoveri. Effectiveness of technical innovation makes the subject matter became more understood by learners, because the material was found alone and practiced by the students, while the response of students to technical innovation of Islamic Education is very good and positive, as it can deliver educators to find their own subject matter.
\end{abstract}

Keywords: inovasi, teknik, efektivitas, respon, ingkuiri, diskoveri.

\begin{abstract}
A. Pendahuluan
Pendidikan sebagai upaya pembangunan sumber daya manusia merupakan solusi atas penguasaan pengetahuan untuk dapat memanfaatkan kemajuan teknologi dalam memudahkan aktivitas kehidupan. Hal ini diungkapkan oleh Cohn dalam Sutaryat Trisnamansyah bahwa "Pendidikan berhubungan erat dengan modal kemanusiaan yang sangat potensial dalam usaha meningkatkan pendapatan hasil kerja seseorang"1
\end{abstract}

\footnotetext{
1 Sutaryat Trisnamansyah, Pengembangan Kualitas Sumber Daya Manusia, (Jakarta: Aksara, 1979). h. 13.
}

\begin{abstract}
Inovasi pendidikan dan pembelajaran merupakan langkah yang tepat dalam mengatasi berbagai permasalahan dalam proses pendidikan umumnya dan proses pembelajaran khususnya. Dengan demikian, inovasi pembelajaran dapat dilaksanakan pendidik untuk memperbaiki kelemahan-kelemahan dalam proses pembelajaran, sehingga dapat mencapai hasil yang maksimal. Pelaksanakan inovasi pembelajaran dalam konteks Pendidikan Agama Islam, sudah saatnya merubah paradigma pengajaran yang selama ini lazim
\end{abstract}


digunakan dalam proses belajar mengajar Pendidikan Agama Islam ke arah paradigma pembelajaran. Hal ini diungkapkan oleh Qowaid dan kawan-kawan bahwa:

Bukan rahasia lagi, bahwa paradigma pembelajaran Pendidikan Agama Islam selama ini masih sarat orientasi belajar mengajar ketimbang pembelajaran. Akibatnya dikalangan peserta didik, Pendidikan Agama Islam sering dipandang sebagai mata pelajaran yang menjemukan, sarat dengan dogma dan indoktrinasi norma-norma agama yang kurang membuka ruang bagi peserta didik untuk lebih kritis dan kreatif dalam proses pembelajaran sehingga peserta didik menjadi malas dan kurang bersemangat mengikuti mata pelajaran ini $^{2}$

Hasil study Xaviery dalam Qowaid dan kawan-kawan menyimpulkan bahwa sekurangkurangnya terdapat tiga masalah pokok yang melatarbelakangi keengganan peserta didik mengikuti suatu mata pelajaran:

Pertama, masalah teknik pembelajaran yang tidak

2 Qowaid, dkk, Inovasi Pembelajaran Pendidikan Agama Islam (SMP) (Jakarta: PT. Pena Citasatria, 2007), h. 6. menumbuhkan motivasi peserta didik. Kedua, eksistensi pendidik bukan sebagai fasilitator yang membelajarkan peserta didik, melainkan pribadi yang mengajar dan menggurui peserta didik dan Ketiga, penyampaian pesan pembelajaran dengan media yang kurang interaktif ${ }^{3}$

Pendidik perlu memahami dinamika perubahan dan mengembangkan kreativitas pendidik yang kapasitasnya untuk menyerap, menyesuaikan diri, menghasilkan atau menolak pembaharuan itu sendiri ${ }^{4}$. Dengan demikian, inovasi pembelajaran merupakan upaya menyelaraskan perkembangan ilmu pengetahuan dan teknologi ke dalam proses pembelajaran dan sekaligus untuk memecahkan berbagai permasalahan dalam proses pembelajaran, sebagaimana pendapat Nurul Zuriah dan Hari Sunaryo "Inovasi dalam bidang pendidikan dan pembelajaran merupakan upaya untuk memecahkan masalah-masalah

\footnotetext{
${ }^{3}$ Ibid, h. 7.

${ }^{4}$ Cece Wijaya, Upaya Pembaharuan dalam Pendidikan dan Pengajaran (Bandung: PT. Remaja Rosdakarya, 1992), h. 4-5.
} 
bidang pendidikan dan pembelajaran"5

Proses pembelajaran yang berkualitas mengacu pada undangundang Sisdiknas bab IX tentang Standar Nasional Pendidikan pasal 35 ayat 1 "Standar nasional pendidikan terdiri atas standar isi, proses, kompetensi lulusan, tenaga kependidikan, sarana dan prasarana, pengelolaan, pembiayaan, dan penilaian pendidikan yang harus ditingkatkan secara berencana dan berkala"6.

Berdasarkan uraian tersebut dapat dipahami bahwa standar nasional pendidikan terdiri dari 8 bagian yang kemudian dijabarkan dalam peraturan pemerintah nomer 19 tahun 2005 tentang Standar Nasional Pendidikan Bab IV Standar Proses pasal 19 ayat 1 , yaitu :

Proses pembelajaran pada satuan pendidikan diselenggarakan secara interaktif, inspiratif, menyenangkan, menantang, memotivasi peserta didik untuk berpartisipasi aktif, serta memberikan ruang yang cukup bagi

\footnotetext{
5 Nurul Zuriah dan Hari Sunaryo, Inovasi Model Pembelajaran Berperspektif Gender, Teori dan Aplikasinya di Sekolah, Cet.I (Malang: UMM Press, 2009), h. 12.

6 Undang-Undang Sisdiknas (Sistem Pendidikan Nasional), Cet.I, (Jakarta: Sinar Grafika, 2003), h. 18.
}

prakarsa, kreativitas dan kemandirian sesuai dengan bakat, minat dan perkembangan fisik serta psikologis peserta $\operatorname{didik}^{7}$

Proses pembelajaran semacam ini, hanya dapat dilaksanakan melalui inovasi pembelajaran, yaitu mendesain pembelajaran yang efektif dengan mempertimbangkan dan menggunakan berbagai hal secara optimal, seperti memilih metode pembelajaran yang sesuai dengan karakteristik materi pelajaran, menciptakan media yang menarik dan memanfaatkan potensi peserta didik sehingga dapat dilibatkan dalam proses pembelajaran. $\mathrm{Di}$ samping itu Win Wenger mengemukakan bahwa proses pembelajaran berkualitas hendaknya juga memperhatikan kondisi individu peserta didik sebagai individu yang unik, dan keunikan itu harus mendapat perhatian dalam proses pembelajaran $^{8}$.

\footnotetext{
${ }^{7}$ Peraturan Pemerintah Republik Indonesia Nomor 19 Tahun 2005 Tentang Standar Nasional Pendidikan, Cet. II, (Jakarta: Sinar Grafika, 2006), h.14.

8 Win Wenger, Beyond Teaching and Learning, diterjemahkan oleh Ria Sirait dan Purwanto dengan judul: Memadukan Quantum Teaching dan Learning, (Jakarta: Nuansa, 2003), h. 89 .
} 
Karakteristik peserta didik menjadi salah satu penentu dalam mempertimbangkan dan menerapkan metode serta media pembelajaran yang tepat sesuai dengan karakteristik peserta didik. Dengan demikian komponen tersebut memiliki keterkaitan yang erat untuk mewujudkan kualitas pembelajaran.

Terkait dengan hal tersebut, penulis tertarik untuk mencermati bagaimana inovasi teknik pembelajaran yang diterapkan pada salah satu sekolah unggulan di kota Medan, yaitu MAN 2 Medan. Sekolah ini memiliki peserta didik dengan karakeristik dan latar belakang yang sangat beragam. Hal ini tentu sangat rentan terhadap konflik dan perpecahan. Namun faktanya, di MAN 2 Medan, nuansa kebersamaan sangat terasa, peserta didik saling menghormati agama yang dianut oleh masing-masing individu dan peserta didik dapat menjalankan rutinitas keagamaan dengan baik tanpa adanya gangguan sehingga aktivitas keagamaan peserta didik sangat kental dalam kesehariannya, misalnya ketika waktu zuhur tiba, peserta didik segera menghentikan aktivitasnya dan langsung menuju masjid, mengumandangkan azan, memberikan kultum, dan menjadi imam salat, seluruh rangkaian ibadah tersebut dilaksanakan oleh peserta didik sendiri bahkan dalam berbelanja makanan dan minuman di kantin sekolah, peserta didik sendiri yang menghitung jumlah tagihan makanan dan minuman yang dikonsumsinya, sehingga tercermin pribadi jujur dalam diri peserta didik.

Hal ini memunculkan pertanyaan yang menarik untuk dikaji, yaitu: bagaimana bentuk inovasi teknik pembelajaran Pendidikan Agama Islam di MAN 2 Medan? Bagaimana efektivitasnya? Dan bagaimana respon peserta didik terhadap inovasi teknik pembelajaran tersebut, sehingga peserta didik dapat mengamalkan ajaran Agama Islam di sekolah tersebut dengan baik?

\section{B. Kajian Pustaka}

Istilah inovasi ${ }^{9}$ menurut Ibrahim dalam Nurul Zuriah dan Hari Sunaryo mengandung makna :

\footnotetext{
9 Secara etimologi, kata inovasi memiliki beberapa pengertian, sebagaimana yang terdapat dalam Kamus Besar Bahasa Indonesia (KBBI) memiliki makna sebagai berikut: “(a) pemasukan atau pengenalan hal-hal yang baru; pembaharuan (b) penemuan baru yang berbeda dari yang sudah ada atau yang sudah dikenal sebelumnya
} 
Suatu ide, hal-hal yang praktis, metode, cara, barang-barang buatan manusia yang diamati atau dirasakan sebagai suatu yang baru bagi seseorang atau kelompok orang (masyarakat). Hal yang baru dapat berupa hasil invensi atau diskoveri yang digunakan untuk mencapai tujuan tertentu atau untuk memecahkan masalah ${ }^{10}$

Dari uraian di atas, dapat dipahami bahwa inovasi memiliki dua makna, yaitu penemuan hal yang baru yang benar-benar baru dan berbeda dari yang sudah ada sebelumnya dan pembaharuan, yaitu pengembangan dari sesuatu atau hal yang sudah ada sebelumnya.

Sehingga ketika kita membicarakan tentang inovasi teknik pembelajaran, maka sasaran penemuan dan pembaruan itu terkait dengan teknik pembelajaran. Teknik pembelajaran yang dimaksud di sini adalah :

Daya upaya, usaha-usaha, cara-cara yang digunakan pendidik untuk melaksanakan pembelajaran di kelas

(gagasan, metode atau alat)". Departemen Pendidikan Nasional. Kamus Besar Bahasa Indonesia, Edisi III, Cet.III, (Jakarta: Balai Pustaka, 2005), h. 435.

${ }^{10}$ Nurul Zuriah dan Hari Sunaryo, h. 11. pada waktu tatap muka dalam rangka menyajikan dan memantapkan bahan pelajaran agar tercapai tujuan pembelajaran saat itu ${ }^{11}$

Artinya, teknik bersifat implementatif dan terjadinya pada tahap pelaksanaan pembelajaran. Teknik pembelajaran merupakan cara-cara yang dilakukan seorang pendidik dalam mengimplementasikan suatu media atau metode secara spesifik. Jika diperhatikan pendidik yang sedang mengajar di kelas, maka yang tampak pada kegiatan pendidik dan peserta didik itu adalah teknik pembelajaran. Secara sederhana teknik pembelajaran adalah siasat atau cara yang dilakukan oleh pendidik dalam melaksanakan kegiatan pembelajaran untuk dapat memperoleh hasil yang optimal.

Dengan demikian, teknik pembelajaran terkait erat dengan dua hal penting yang saling berhubungan dalam proses pembelajaran, yaitu: metode dan media pembelajaran.

- Metode Pembelajaran

Metode pembelajaran pada dasarnya merupakan langkah-

\footnotetext{
${ }^{11}$ Herlin Andriyeni, Teknik Pembelajaran (http://herlin-andriyeni. blogspot.com), diakses pada tanggal 30 Desember 2012.
} 
langkah yang sistematis, terukur dan

cermat yang dihasilkan berdasarkan serangkaian perenungan, pengamatan dan pendalaman dengan menggunakan berbagai konsep dan teori yang terdapat dalam ilmu jiwa, filsafat, sosial, dal lainnya. Itulah sebabnya para ahli pendidikan sepakat, bahwa seorang pendidik yang ditugaskan melaksanakan proses pendidikan di sekolah, haruslah pendidik yang profesional, yaitu pendidik yang antara lain ditandai oleh penguasaan yang prima terhadap metode pembelajaran. Hal ini sebagaimana diuraikan oleh Abuddin Nata, bahwa:

Metode pengajaran memiliki kedudukan yang amat strategis....melalu metode pengajaran mata pelajaran dapat disampaikan secara efesien, efektif dan terukur dengan baik sehingga dapat dilakukan perencanaan dan perkiraan dengan tepat. Terdapat sejumlah bukti yang menjelaskan, bahwa hasil pengajaran yang berbeda antara yang diberikan oleh sebuah lembaga pendidikan lainnya antara lain disebabkan karena adanya perbedaan metode pengajaran yang digunakannya $^{12}$.

Perbedaan penggunaan metode pembelajaran dalam suatu lembaga pendidikan, dapat menghasilkan output yang berbeda pula, walaupun pada materi pelajaran yang sama. Oleh karena itu, penggunaan metode pembelajaran sangat menentukan bukan hanya peningkatan hasil belajar peserta didik tetapi juga kompetensi atau kemampuan yang dimiliki oleh peserta didik.

Pemilihan berbagai metode pembelajaran dalam melaksanakan proses pembelajaran, memiliki pertimbanganpertimbangan tertentu. Menurut Winarno Surakhmad dalam Syaiful Bahri Djamarah, berbagai hal yang dijadikan dasar pertimbangan dalam pemilihan metode pembelajaran sebagai berikut :

- Tujuan dengan berbagai jenis dan fungsinya.

- Anak didik dengan berbagai tingkat kematangannya.

- Situasi dengan berbagai keadaannya.

${ }^{12}$ Abuddin Nata, Perspektif Islam Tentang Strategi Pembelajaran, Edisi.I, Cet. II, (Jakarta: Kencana Media Prenada Group, 2011), h. 177. 
- Fasilitas dengan berbagai kualitas dan kuantitasnya.

- Pribadi guru serta kemampuan profesinya yang berbeda-beda. ${ }^{13}$ Pemilihan suatu metode pembelajaran memiliki berbagai pertimbangan sebagaimana tersebut diatas. Berbagai pertimbangan tersebut dimaksudkan agar metode pembelajaran yang telah dipilih oleh guru dapat diterapkan dengan baik dengan hasil belajar peserta didik yang maksimal, karena setiap materi pelajaran memiliki karakteristik yang berbeda, sehingga memungkinkan pemilihan metode tertentu yang sesuai dengan karakteristik tersebut. selain itu potensi peserta didik dan fasilitas pendukung juga sangat menentukan pemilihan suatu metode pembelajaran.

- Media Pembelajaran

Media pembelajaran menurut

Rossi dan Breidle, adalah:

Seluruh alat dan bahan yang dapat dipakai untuk tujuan pendidikan seperti radio, televisi, buku, koran, majalah dan sebagainya. Alat-alat seperti televisi dan

${ }^{13}$ Syaiful Bahri Djamarah, Guru dan Anak Didik dalam Interaksi Edukatif, Cet.I, (Jakarta: PT. Rineka Cipta, 2000), h. 184-185. radio kalau digunakan dan diprogram untuk pendidikan, maka merupakan media pembelajaran $^{14}$

Berdasarkan pendapat ini, media pembelajaran sangat beragam, mulai dari media cetak (visual), media audio sampai media audio visual. Keseluruhan media pembelajaran tersebut dimaksudkan agar peserta didik memperoleh pengetahuan yang maksimal dari materi pelajaran yang disampaikan oleh pendidik dan proses pembelajaran menjadi menarik.

Oleh karena itu, Inovasi teknik media pembelajaran merupakan suatu perubahan menuju ke arah perbaikan, tentang cara-cara pelaksanaan atau penggunaan media pembelajaran yang dilakukan oleh pendidik dengan sengaja dan terencana agar dapat menciptakan proses pembelajaran yang menarik sehingga memotivasi peserta didik untuk mengikuti proses pembelajaran dan akhirnya dapat mencapai tujuan dari pembelajaran.

\footnotetext{
${ }^{14}$ Rossi dan Breidle dalam Wina Sanjaya, Perencanaan dan Desain Sistem Pembelajaran, Cet.II, (Jakarta: Kencana Prenada Media Group, 2009), h. 204.
} 
Media pembelajaran yang digunakan sebagai alat bantu dalam peroses pembelajaran berfungsi untuk: "Membangkitkan keinginan dan minat baru, membangkitkan motivasi dan ransangan kegiatan belajar dan bahkan membawa pengaruh psikologis terhadap peserta didik" $"$ Dengan demikian penggunaan media pembelajaran dapat membawa manfaat besar bagi pendidik, peserta didik dan terhadap keberhasilan pelaksanaan kegiatan pembelajaran di kelas.

Wina Sanjaya menambahkan fungsi media pembelajaran, sebagaimana uraian di bawah ini :

- Menangkap suatu objek atau peristiwa-peristiwa tertentu.

- Memanipulasi keadaan, peristiwa atau objek tertentu.

- Menambah gairah dan motivasi siswa.

- Media pembelajaran memiliki nilai praktis seperti ; mengatasi keterbatasan pengalaman yang dimiliki oleh siswa, mengatasi batas ruang kelas, memungkinkan terjadi interaksi langsung antara peserta didik

15 Omar Hamalik, Keterampilan Dasar Mengajar, (Malang: Fakultas Tarbiyah, 2005), h. 26. dan lingkungan, menanamkan konsep dasar yang benar, nyata dan sebagainya. ${ }^{16}$

Berdasarkan pemaparan di atas, dapat dipahami bahwa media pembelajaran memiliki fungsi yang signifikan dalam proses pembelajaran seperti mengabadikan peristiwa-peristiwa penting atau objek-objek langka ke dalam foto atau direkam ke dalam audio atau video, memanipulasi keadaan, peristiwa atau objek tertentu yang abstrak dan menyajikannya secara kongkrit sehingga mudah dipahami. Dengan demikian penggunaan media pembelajaran menghilangkan verbalisme, hal tersebut menjadikan proses pembelajaran menjadi inovatif dan menambah motivasi belajar peserta didik.

Ahmad Syahid menambahkan bahwa manfaat media pembelajaran yang digunakan dalam proses pembelajaran dapat dirasakan pendidik pendidik maupun peserta didik, sebagaimana uraian berikut:

- Bahan ajar akan lebih jelas maknanya dan tidak terlalu verbalistis (dalam bentuk lisan atau tertulis semata), sehingga

${ }^{16}$ Wina Sanjaya, h. 208-209. 
mudah dipahami oleh pebelajar dan memungkinkan menguasai tujuan pembelajaran dengan baik;

- Metode pembelajaran akan lebih bervariasi, tidak sematamata komunikasi verbal melalui penuturan kata-kata oleh pengajar, sehingga pebelajar tidak bosan;

- Pebelajar lebih banyak melakukan kegiatan pembelajaran, sebab tidak hanya mendengarkan uraian pengajar, tetapi juga kegiatan lain, seperti mengamati, mendemonstrasikan dan lain-lain;

- Pembelajaran akan lebih menarik perhatian pebelajar sehingga dapat menumbuhkan motivasi belajar, dan

- Mengatasi keterbatasan ruang, waktu dan daya indera ${ }^{17}$

Dengan memanfaatkan media pembelajaran proses pembelajaran menjadi lebih optimal, karena peserta didik dapat melakukan berbagai hal seperti mendemonstrasikan, mengamati, berkomunikasi dan lain sebagainya dan tidak semata-mata

$17 \quad$ Ahmad $\quad$ Syahid, Rancangan
Pembelajaran Terapan Model Elaborasi, Edisi. I,
Cet. II, (Jember: Sains, 2008), h. 179.

hanya menyimak uraian pendidik, dengan demikian, materi pelajaran dapat diserap dengan baik oleh peserta didik. Penggunaan media pembelajaran juga dapat bermanfaat bagi pendidik, yaitu pendidik dapat menyajikan proses pembelajaran yang menarik sehingga proses pembelajaran menjadi diminati oleh peserta didik.

Azhar

Arsyad

mengklasifikasikan media pembelajaran menjadi tiga kelompok yaitu: media berbasis visual, media berbasis audio-visual, media berbasis komputer. Ketiga kelompok media pembelajaran tersebut dapat diuraian sebagai berikut:

- Media Berbasis Visual

Media berbasis visual memegang peranan penting dalam proses pembelajaran, media visual dapat memperlancar pemahaman dan memperkuat ingatan, sehingga penggunaan media visual dapat menambah minat peserta didik dalam belajar. Menurut Wina Sanjaya, media ini merupakan "Media yang mengadung pesan yang dituangkan dalam bentuk tulisan, hurufhuruf, gambar dan simbol-simbol yang 
mengandung arti"18. Dengan demikian, media dalam kategori ini memanfaatkan indera penglihatan sebagai sasarannya. Adapun bentuk media visual dapat berupa:

(a) gambar representasi seperti gambar lukisan atau foto yang menunjukkan bagaimana tampaknya suatu benda (b) diagram yang melukiskan hubungan-hubungan konsep, organisasi dan struktur materi (c) peta yang menunjukkan hubungan-hubungan ruang antara unsurunsur dalam isi materi dan (d) grafik seperti tabel grafik dan chart (bagan) yang menyajikan gambaran/ kecenderungan data atau antar hubungan seperangkat gambar atau angka-angka. ${ }^{19}$

$\begin{array}{rrr}\text { Media } & \text { visual memiliki } \\ \text { peran penting dalam penyajian }\end{array}$ materi pelajaran agar lebih kongkrit, sehingga mudah dipahami oleh peserta didik. Macam-macam media visual dalam uraian di atas terdiri dari gambar, diagram, peta dan grafik. Dari beragam jenis media visual tersebut, media visual juga memiliki beragam fungsi, seperti

\footnotetext{
${ }^{18}$ Wina Sanjaya,..., h. 214.

${ }^{19}$ Azhar Arsyad. Media Pembelajaran, Cet.I, (Jakarta: PT. Raja Grafindo Persada, 2008), h.91-92.
}

dikemukakan oleh Joko Purwanto berikut :

(a) fungsi atensi yaitu menarik dan mengarahkan perhatian peserta didik untuk berkonsentrasi kepada isi pembelajaran yang berkaitan dengan makna visual yang ditampilkan, (b) fungsi afektif yang dapat mengubah emosi dan sikap peserta didik, (c) fungsi kognitif yang memperlancar pencapaian tujuan untuk memahami dan mengingat informasi atau pesan yang terkandung dalam gambar, dan (d) kompensatoris yaitu memberikan konteks untuk memahami teks dan memabantu peserta didik yang lemah dalam membaca dan mengorganisasikan informasi ${ }^{20}$

Keempat fungsi tersebut, menunjukkan bahwa penggunaan media pembelajaran dapat meningkatkan kualitas hasil pembelajaran yang diperoleh peserta didik karena ketiga komponen kognitif, afektif dan psikomotorik dalam proses belajar mengajar dapat dipacu. Penggunaan media dapat mempertinggi hasil dan prestasi belajar peserta didik dan sekaligus dapat mendukung dan mendorong

\footnotetext{
${ }^{20}$ Joko Purwanto, Prinsip-Prinsip dan Teknik Evaluasi Pengajaran, (Bandung: Sinar Baru, 1989), h. 32.
} 
peserta didik yang memiliki kemampuan yang terbatas dalam menerima informasi dan pesan dalam proses pembelajaran yang berlangsung. Efektivitas penggunaan media terhadap proses pembelajaran tersebut terjadi karena dalam proses penggunaannya peserta didik dilibatkan tidak hanya dalam benak ataupun mentalnya saja akan tetapi dapat memperhatikan mereka dan menyaksikan secara langsung informasi yang disampaikan dalam proses belajar mengajar tersebut.

- Media Berbasis Audio Visual

Media audio visual merupakan media yang menggabungkan visualisasi dan suara. Dengan demikian media ini melibatkan rangsangan indera penglihatan dan indera pendengaran. Contoh dari media ini adalah media video. Media ini merupakan salah satu jenis media audio visual, selain film. Yang banyak dikembangkan untuk keperluan pembelajaran, biasa dikemas dalam bentuk VCD.

Manfaat dari media ini adalah "Dapat menampilkan pesan yang memotivasi peserta didik" Hal ini dapat dipahami karena

\footnotetext{
${ }^{21}$ Azhar Arsyad,..., h. 148.
}

penggunaan media audio-visual melibatkan indera penglihatan dan pendengaran peserta didik, sehingga materi pelajaran yang disajikan menjadi lebih menarik. Hal tersebut merupakan langkah yang tepat dalam memotivasi peserta didik untuk mengikuti dan memahami pembelajaran yang disajikan pendidik.

- Media Berbasis Komputer Media komputer digunakan dalam keperluan administrasi dan pengembangan usaha, komputer juga dapat digunakan di sekolah-sekolah sebagai media pembelajaran. Menurut Wina Sanjaya, Media berbasis komputer merupakan "media yang secara virtual dapat menyediakan respon yang segera terhadap hasil belajar peserta didik. Media komputer juga memiliki kemampuan menyimpan dan memanipulasi informasi sesuai dengan kebutuhan",22. Berdasarkan pendapat tersebut, dipahami bahwa media ini memiliki semua kelebihan yang dimiliki oleh media lain. Selain mampu menampilkan teks, gerak, suara dan gambar, komputer juga dapat digunakan secara interaktif,

${ }^{22}$ Wina Sanjaya,..., h. 218. 
bukan hanya searah. Bahkan

komputer yang disambung dengan internet dapat memberikan keleluasaan belajar menembus ruang dan waktu serta menyediakan sumber belajar yang hampir tanpa batas. Hal ini sebagaiman dijelaskan oleh Azhar Arsyad bahwa "peran komputer dalam proses pembelajaran adalah pemanfaatannya meliputi penyajian isi materi dan sekaligus proses pelatihan. Komputer dapat menyajikan informasi dan tahap pembelajaran yang tidak dimiliki oleh media lannya"23. Dengan kelebihan dari media ini, pendidik dapat menciptakan proses pembelajaran yang benar-benar melibatkan peserta didik didalamya, sehingga aktivitas pembelajaran menjadi aktif dan menyenangkan. Aktivitas pembelajaran yang menyenangkan tersebut membuat pembelajaran menarik dan meningkatkan pemahaman peserta didik.

\section{Metode penelitian

Penelitian ini bersifat
kualitatif, yakni berupaya
menghimpun data, mengolah dan
menganalisa secara kualitatif dan

\footnotetext{
${ }^{23}$ Wina Sanjaya,... h. 163.
}

mendefenisikannya secara kualitatif pula. ${ }^{24}$ Penelitian kualitatif umumnya lebih longgar terhadap instrumen pengumpulan data dan lebih fokus pada proses dari pada produk suatu objek penelitian, ${ }^{25}$ sehingga penelitian kualitatif dilakukan berdasarkan pengumpulan data akurat di lapangan. ${ }^{26}$ Penelitian kualitatif dapat didefinisikan sebagai suatu penelitian interpretatif terhadap suatu masalah, di mana peneliti merupakan sentral dari pengertian dan pemaknaan yang dibuat mengenai masalah itu.

Pengumpulan data dilakukan melalui metode observasi, wawancara mendalam dan dokumentasi. Sedangkan analisis data yang digunakan adalah analisis interaktif Miles dan Huberman, yaitu: analisis Interaktif Model. Teknik analisis ini pada dasarnya terdiri dari 3 komponen yaitu: reduksi data, penyajian data dan

\footnotetext{
${ }^{24}$ Wardi Bachtiar, Metodologi Penelitian Ilmu Dakwah, Cet. I, (Jakarta: Logos, 1997), h. 21.

${ }^{25}$ Noeng Muhadjir, Metodologi Penelitian Kualitatif, Edisi IV, Cet.I, (Yogyakarta: Rake Sarasin, 2000), h. 43.

${ }^{26}$ Lihat: Robert Bodgan dan Steven J. Taylor, Instrduction to Qualitative Research Method, New York, John Wiley \& Sons, h. 4; Fred N. Kaelinger. Foundation of Behavioral Research, (New York: Hold Rinehart and Winston,1973), h. 525.
} 
penarikan serta pengujian kesimpulan. $^{27}$

\section{Hasil Penelitian}

Bentuk Inovasi Teknik

Pembelajaran Pendidikan Agama

Islam di MAN 2 Medan

Pelaksanaan

proses

pembelajaran Pendidikan Agama

Islam yang dikembangkan di MAN 2

Medan merupakan proses

pembelajaran yang diarahkan kepada

tiga tahap pembelajaran, yaitu: tahap

orientasi materi dan pemberian tugas,

tahap persentase kelompok dan tahap

praktek. Jika dianalisis secara

mendalam pengembangan

pembelajaran Pendidikan Agama

Islam tersebut adalah menggunakan

metode diskoveri dan inkuiri atau

disebut dengan metode penemuan.

Metode penemuan memiliki

pengertian "cara menyajikan

pelajaran yang banyak melibatkan

siswa dalam proses-proses mental

dalam rangka menemukan sesuatu

yang diperlukan untuk

pengembangan, penyempurnaan dan

perbaikan konsep" 28

\footnotetext{
${ }^{27}$ Pawito, Penelitian Komunikasi Kualitatif, (Yogyakarta: PT. LKiS Pelangi Aksara, 2007), h. 104.

${ }^{28}$ Abuddin Nata,..., h. 195.
}

Sedangkan E. Mulayasa
berpendapat bahwa "Penemuan (discovery) merupakan metode yang lebih menekankan pada pengalaman langsung. Pembelajaran dengan metode penemuan lebih mengutamakan proses daripada hasil

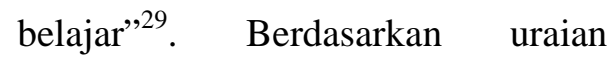
tersebut metode diskoveri dan inkuiri merupakan metode yang melibatkan peserta didik agar menemukan sendiri fakta-fakta dan konsep dari materi pelajaran yang dipelajari. Dengan kata lain metode ini membiasakan peserta didik untuk belajar menemukan hal-hal yang harus diketahui oleh peserta didik dan lebih mengutamakan keterlibatan peserta didik dalam proses pembelajaran. Metode ini memerlukan persiapan dalam proses pelaksanaannya. Abuddin Nata menjelaskan persiapan yang harus dilakukan dalam melaksanakan metode ini, sebagaimana pemaparan berikut:

Untuk dapat melaksanakan metode penemuan ini diperlukan langkah persiapan antara lain penemuan masalah yang akan ditemukan,

\footnotetext{
${ }^{29}$ E. Mulyasa, Menjadi Guru Profesional, (Bandung: PT. Remaja Rosdakarya, 2006), h. 110 .
} 
peralatan yang diperlukan, laboratorium, bahan-bahan habis pakai, petugas pendamping, instruktur, dan lain sebagainya ${ }^{30}$

Berdasarkan uraian di atas dapat dipahami bahwa dalam melaksanakan metode diskoveri dan inkuiri memerlukan berbagai persiapan yang matang. Namun demikian berbagai persiapan yang dikemukakan diatas adalah pelaksanaan metode diskoveri dan inkuiri secara murni, misalnya untuk menemukan teori dan konsep pada jenis kimia atau fisika murni, atau pelaksanaan metode diskoveri dan inkuiri pada mata pelajaran lain, misalnya mata pelajaran biologi yang memerlukan percobaan percobaan di laboratorium. Perbedaannya dengan mata pelajaran Pendidikan Agama Islam di MAN 2 Medan pelaksanaan metode pembelajaran tersebut, juga memerlukan persiapan-persiapan antara lain: masalah yang harus ditemukan, ketersediaan sumber referensi dapat memanfaatkan perpustakaan dan internet, alat tulis menulis dan pendidik sebagai pembimbing.

Penutup

\footnotetext{
${ }^{30}$ Abuddin Nata,..., h. 195.
}

Bentuk inovasi teknik pembelajaran pendidikan agama Islam di MAN 2 Medan yang dilaksanakan berupa pengembangan metode diskoveri dan ingkuiri. Biasanya metode ini dilaksanakan dalam satu kali tatap muka, namun implementasi metode ini di MAN 2 Medan dilaksanakan dalam tiga tahap, yaitu tahap orientasi materi dan pemberian tugas kelompok, tahap diskusi kelompok dan tahap praktek. Aspek penggunaan media pembelajaran di MAN 2 Medan, berupa variasi pemanfaatan infokus misalnya untuk menyajikan materi dan pemutaran video yang berkenaan dengan materi pelajaran, penggunaan media tiruan benda asli dan media praktek secara langsung, hal ini juga menambah pemahaman peserta didik terhadap materi pelajaran.

Efektivitas inovasi teknik pembelajaran Pendidikan Agama Islam berupa pengembangan metode diskoveri dan ingkuiri dan penggunaan media pembelajaran yang variatif membuat materi pelajaran menjadi lebih dipahami oleh peserta didik, karena materi tersebut ditemukan sendiri dan dipraktekkan oleh peserta didik, 
sehingga peserta didik di MAN 2 Medan dapat mengamalkan materi pelajaran dalam kehidupan seharihari.

Respon peserta didik terhadap inovasi teknik pembelajaran Pendidikan Agama Islam sangat baik dan positif, karena proses pembelajaran yang dikembangkan oleh pendidik mengantarkan pendidik untuk menemukan sendiri materi pelajaran dan kegiatan praktek yang dilaksanakan membuat lebih memahami materi pelajaran tersebut.

\section{Daftar Pustaka}

Andriyeni, H. (2012). Teknik Pembelajaran (http://herlinandriyeni. blogspot.com), diakses pada tanggal 30 Desember.

Arsyad, A. (1997). Media Pembelajaran, Cet.I, Jakarta: PT. Raja Grafindo Persada.

Bachtiar, W. (1997). Metodologi Penelitian Ilmu Dakwah, Cet. I, Jakarta: Logos.

Bodgan, R dan Taylor, S. J. (1975). Instrduction to Qualitative Research Method, New York, John Wiley \& Sons.
Departemen Pendidikan Nasional. (2005). Kamus Besar Bahasa Indonesia, Edisi III, Cet.III, Jakarta: Balai Pustaka.

Djamarah, S,B. (2000). Guru dan Anak Didik dalam Interaksi Edukatif, Cet.I, Jakarta: PT. Rineka Cipta.

Hamalik, O. (2005). Keterampilan Dasar Mengajar, Malang: Fakultas Tarbiyah.

Kaelinger, F.N. (1973). Foundation of Behavioral Research, New York: Hold Rinehart and Winston.

Muhadjir, N. (2000). Metodologi Penelitian Kualitatif, Edisi IV, Cet.I, Yogyakarta: Rake Sarasin.

Mulyasa, E. (2006). Menjadi Guru Profesional, Bandung: PT. Remaja Rosdakarya.

Nata, A. (2011). Perspektif Islam Tentang Strategi Pembelajaran, Edisi.I, Cet. II, Jakarta: Kencana Media Prenada Group.

Pawito. (2007). Penelitian Komunikasi Kualitatif, Yogyakarta: PT. LKiS Pelangi Aksara. 
Peraturan Pemerintah Republik

Indonesia Nomor 19 Tahun

2005 Tentang Standar Nasional

Pendidikan. (2006). Cet. II,

Jakarta: Sinar Grafika.

Purwanto, J. (1989). Prinsip-Prinsip

dan Teknik Evaluasi

Pengajaran, Bandung: Sinar

Baru.

Qowaid, dkk. (2007). Inovasi Pembelajaran Pendidikan Agama Islam (SMP), Cet. I, Jakarta: PT. Pena Citasatria.

Sanjaya, W. (2009). Perencanaan dan Desain Sistem Pembelajaran, Cet.II, Jakarta: Kencana Prenada Media Group.

Syahid, A. (2008). Rancangan Pembelajaran Terapan Model Elaborasi, Edisi. I, Cet. II, Jember: Sains.

Trisnamansyah, S. (1979). Pengembangan Kualitas Sumber Daya Manusia, Jakarta: Aksara.

Undang-Undang Sisdiknas (Sistem

Pendidikan Nasional). (2003), Cet.I, Jakarta: Sinar Grafika.

Wenger, W. (2003). Beyond Teaching and Learning, diterjemahkan oleh Ria Sirait dan Purwanto dengan judul: Memadukan Quantum Teaching dan Learning, Jakarta: Nuansa.

Wijaya, C, dkk. (1992). Upaya Pembaharuan dalam Pendidikan dan Pengajaran, Bandung: PT. Remaja Rosdakarya.

Zuriah, N dan Sunaryo, S. (2009). Inovasi Model Pembelajaran Berperspektif Gender, Teori dan Aplikasinya di Sekolah, Cet.I; Malang: UMM Press. 